\title{
Coupling and uncoupling between nitrate uptake and growth rate in Prorocentrum minimum (Dinophyceae) under different frequencies of pulsed nitrate supply
}

\author{
Antoine Sciandra \\ Station Zoologique, B. P. 28, Villefranche-sur-Mer, F-06230, France
}

\begin{abstract}
Nitrate uptake and growth rates of the red-tide dinoflagellate Prorocentrum minimum were measured in a chemostat culture system in which nitrate was added in the same total amounts every 1,2 or $3 \mathrm{~d}$. In comparison with continuous nitrate supply, the rate of cell division was not affected by the 1 or 2 d pulse treatments, whereas it fell drastically when a nitrogen source was added only every $3 \mathrm{~d}$. Delayed steady uptake rates were reached during the 1 or $2 \mathrm{~d}$ pulse phases, which reflected a mid-term adaptation of the cell uptake process under discontinuous nutrient supply. This adaptation permitted $P$. minimum to maintain a steady growth rate under these regimes. During the $3 \mathrm{~d}$ pulse treatment, the maximal uptake rate measured during each pulse experıment increased considerably, which reflected a long-term adaptation, but was not sufficient to maintain the initıal growth rate. For low frequencies of nitrate supply, uptake and growth rate became largely uncoupled. It is concluded that $P$. minimum is a species able to form a large internal pool of nitrogen which constitutes a competitive advantage. This is discussed in the light of in situ observations.
\end{abstract}

\section{INTRODUCTION}

The realization that the surface mixed layer is not a constant environment, and the verification that the physiological processes of phytoplankton are adapted to a fluctuating environment (Harris 1986), has resulted in major studies of nutrient uptake and growth rates under unsteady conditions during the last decade.

When the growth processes are far from stationary, classical models such as those of Monod (1942) or Droop (1968) present relationships which are not adequate to represent correctly the details of growth and nutrient removal. Numerous cases of uptake curves that do not fit these models can be found in the literature (Cunningham \& Maas 1978, Goldman \& McCarthy 1978, Burmaster 1979, DeManche et al. 1979, Murphy 1980, McCarthy 1981, Cunningham 1984). These discrepancies were originally demonstrated by submitting nutrient-limited cells to a single pulse of the limiting nutrient (Conway et al. 1976). The single pulse addition represents an extreme case in variation of a limiting resource since the rate of its increase is infinite. Even if such impulses are unlikely in the sea given the spatial diffusion which smooths steep variations, such experiments are useful in revealing the diversity of possible adaptations in different phytoplankton species. Under non-steady state conditions, uptake and storage of the major nutrients become highly complex, due to the integrative nature of cellular physiology and the priority given to synthesis of cellular constituents (Harris 1986). The diversity in the type of adaptation observed - for example surge or enhanced uptake, and latency times - reflects the complexity of the adaptative processes which can differ from one species to another (Collos 1986).

The study of these adaptative processes in the marine environment is arduous, not only because these processes are non-linear and thus difficult to analyse, but also because the patterns of Lagrangian variations in the limiting nutrients in situ are complex and poorly known (McCarthy \& Altabet 1984, Marra et al. 1990). Some mathematical models predict specific frequencies of nutrient fluctuations such as nitrate pulses through the nitracline (Woods \& Wiley 1972, Klein \& Coste 1984). Despite the fact that more complex patterns of variation probably exist, given the simultaneity 
and diversity of physical processes which maintain the dynamic instabilities of the environment (Denman \& Gargett 1983), we can use periodicity of variation to characterize the dynamic variability of events in the sea (Harris 1984).

Since the availability of nutrients to phytoplankton is highly variable, it is logical to measure uptake and growth of phytoplanktonic cells submitted to nutrient pulses at different intervals and concentrations. Results of Suttle et al. (1987), Olsen et al. (1989), Sommer (1985) and others illustrate that it is no longer possible to explore the question of competition between species without considering the time variation patterns of limiting nutrients. Quarmby et al. (1982) have shown that periodical additions of nitrate to cultured diatoms may alter their growth kinetics when compared with a continuous nitrate supply. Unfortunately, these studies have generally been performed with a constant frequency of variation of the limiting nutrient and consequently cannot illustrate the diversity of possible cell behaviour at different frequencies of variation.

Moreover, phytoplankton species are usually preconditioned before nutrient addition in experimental studies in a continuous culture system, so that internal nutrient pools are stabilized at a level adapted to the flow rate. The nutrient pulses are then performed on cells which are assumed to be in a stationary state, which is an improbable situation in the sea. By submitting phytoplankton cultures to pulses at different frequencies, it is possible to analyse the uptake and growth processes of cells which are more or less far from the steady state. It is clear that the time lapse between 2 pulses and their amplitudes are crucial parameters since the lapse influences the physiological state of cells before each pulse (Collos 1980).

Such an approach is tedious because a great amount of data is necessary to analyse the non-linearity of the observed kinetics (Goldman et al. 1981, Collos 1983, Harrison et al. 1989). Mathematical formalizations such as the model of Turpin et al. (1981) have previously attempted to develop theoretical frameworks to explore the effects of limiting intermittent nutrient supply on phytoplankton growth. However, given the complexity of energy input and utilization by the cells induced by nutrient fluctuations (Dortch 1982), such models are probably poorly predictive, especially if they represent growth and uptake rates with steadystate relationships. I present in this paper the results of an experimental study whose goal was to follow the uptake and growth processes of the dinoflagellate Prorocentrum minimum (Dinophyceae) submitted to nitrate pulses added at various frequencies and amplitudes. $P$. minimum is a species whose distribution and growth dynamics have been extensively studied in relation to physical factors in the environment (Tyler \&
Seliger 1978, 1981). Ecological implications of our results on the red tides caused by this species are discussed.

\section{MATERIAL AND METHODS}

The strain of Prorocentrum minimum was obtained from the culture collection UTEX at the University of Texas at Austin, USA, and grown to steady state in a $3.31 \mathrm{NO}_{3}$-limited continuous culture at a dilution rate of $0.16 \mathrm{~d}^{-1}$. The temperature was maintained at $18 \pm 0.1^{\circ} \mathrm{C}$ and the culture was continuously illuminated at $200 \mu \mathrm{Ein} \mathrm{m}^{-2} \mathrm{~s}^{-1}$ with a halogen lamp (quartz iodine, HQI 300 W). Mixing was effected by bubbling air filtered through a $0.22 \mu \mathrm{m}$ autoclaved filter, and by stirring at $100 \mathrm{rpm}$. Inflowing medium during continuous nitrate supply was natural seawater from $500 \mathrm{~m}$ depth, previously exposed to continuous illumination for $1 \mathrm{wk}$ to exhaust residual inorganic nitrogen. It was then filtered through a $0.22 \mu \mathrm{m}$ filter, autoclaved at $105^{\circ} \mathrm{C}$ and enriched with phosphate, trace metals, and vitamins to a concentration of $f / 2$ (Guillard \& Ryther 1962), and nitrate as $\mathrm{NaNO}_{3}$ to a concentration of $42 \pm 1 \mu \mathrm{g}$-at. $1^{-1}$. New inflowing media were prepared every $20 \mathrm{~d}$ to prevent possible degradation. Although the culture system was initiated under axenic conditions, it is possible that axenicity was not maintained during the overall experiment duration, because of the multiple probes connected to the reactor vessel. The presence or absence of bacteria was not confirmed. The fact that the cell population returned to its initial steady-state concentration at the end of the experiment suggests firstly that bacterial activity, if it existed, had no noticeable effects on the nitrogen balance in the chemostat, and secondly that the P. minimum cells were not affected by the $70 \mathrm{~d}$ duration experiment. During pulsed phases (except during the first nitrate pulse addition) which were begun once steady state was obtained, dilution was maintained with the same inflow medium, but without nitrate. Pulsed nitrate was added separately with a peristaltic pump where the culture received the same amount of nitrogen per $24 \mathrm{~h}$ as in the continuous regime.

Culture samples were collected daily or twice a day for cell counts. Cells were immediately fixed in glutaraldehyde and counted with a Lemaur hemacytometer. Inorganic nitrogen concentration was monitored with an Autoanalyser Technicon II. The culture was pumped directly into the reactor vessel with a sampling needle surrounded with a $8 \mu \mathrm{m}$ mesh net to prevent cells from entering the Autoanalyser system. Inorganic nitrogen was measured (Tréguer \& Le Corre 1975) with a precision of $3 \%$, without distinction between nitrate and nitrite. Ammonium was monitored weekly, but was 
never detected. Inorganic nitrogen, $\mathrm{pH}$ and temperature acquisitions, and pulsed or continuous regimes were monitored with an automatic system including an Apple II, electronic interfaces for data acquisition, valves, peristaltic pumps and software developed at the Marine Station at Villefranche-sur-Mer (Malara \& Sciandra unpubl.).

Dilution rate was maintained constant during the overall time experiment so the instantaneous rate of variation of the limiting nutrient in the chemostat can be written as:

$$
\frac{\mathrm{d} x}{\mathrm{~d} t}=-\rho_{(x)} y+D(C-x)
$$

where $x\left(\mu g\right.$-at. $\left.\mathrm{N}^{-1}\right)$ and $y\left(\right.$ cell $\left.l^{-1}\right)=$ respectively the concentration of inorganic nitrogen and cells in the chemostat; $\rho_{(x)}\left(\right.$ ug-at. $\left.\mathrm{N} \mathrm{cell}^{-1} \mathrm{~h}^{-1}\right)=$ the hourly uptake rate of nitrogen; $D\left(\mathrm{~h}^{-1}\right)=$ the dilution rate; and $\mathrm{C}$ ( $\mu \mathrm{g}$-at. $\mathrm{N}^{-1}$ ) = the concentration of nitrate in the inflow medium. For perturbation experiments where a constant rate of uptake was sustained for a certain time before limitation by nutrient, the kinetics were assumed to obey the Michaelis-Menten relationship

$$
\rho_{(x)}=\rho_{\mathrm{m}} \frac{x}{k_{\mathrm{N}}+x}
$$

where $\rho_{\mathrm{m}}\left(\mu \mathrm{g}\right.$-at. $\mathrm{N}$ cell $\left.{ }^{-1} \mathrm{~h}^{-1}\right)=$ the maximum uptake rate; and $k_{N}\left(\mu g\right.$-at. $\left.\mathrm{N}^{-1}\right)=$ the half-saturation constant. Estimates of $k_{N}$ and $\rho_{m}$ were obtained with the Gauss-Marquard algorithm used for non-linear regression. The variation rate of the nutrient concentration (Eq. 3) was fitted to the values estimated over 2 consecutive measurements of nitrogen concentration (Eq. 4). $x$ was calculated from Eq. (5).

$$
\begin{aligned}
& \frac{\mathrm{d} x}{\mathrm{~d} t}=-\rho_{\mathrm{t}} \frac{x}{k_{\mathrm{N}}+x} y+D(C-x) \\
& \frac{\Delta x}{\Delta t}=\frac{x_{t}+\Delta t-x_{t}}{\Delta t} \\
& x=\frac{x_{t}+x_{t}+\Delta t}{2}
\end{aligned}
$$

Growth rate was estimated from the slope of a continuous polynomial function fitted to the cell counts which represents their mean concentration with time:

$$
\mu=\frac{1}{\Delta t} \ln \left(\frac{y_{t}+\Delta t}{y_{t}}\right)+D
$$

\section{RESULTS}

Fig. 1 shows the nitrate concentration and cell counts during the $70 \mathrm{~d}$ time-course experiment. Once the $200 \mu \mathrm{g}$-at. $\mathrm{N} \mathrm{l}^{-1}$ remaining in the batch culture were completely exhausted by the cells, the culture received medium with nitrate. This produced a transient accumulation of inorganic nitrogen which was rapidly taken up by the exponentially growing cells ( $\mu=$ $0.33 \mathrm{~d}^{-1}$ during the exponential phase). No inorganic nitrogen was detectable (less than $0.02 \mu \mathrm{g}$-at. $\mathrm{N}^{-1}$ ) at Day 8 , but cell concentration increased up to Day 12 . At this time, the population in the chemostat reached a plateau and the culture was considered to be at steady state. Table 1 gives the different patterns of nitrate influx into the chemostat

The pulsed supplies of nitrogen did not significantly affect the growth rate until Day 30 , in comparison with
Fig. 1. Time variation of Prorocentrum minimum (dots and fitted curve) and inorganic nitrogen concentration (thin line) in the chemostat. During the pulsed phase (except during the first pulse), the continuous inflow medium was deprived of nitrate

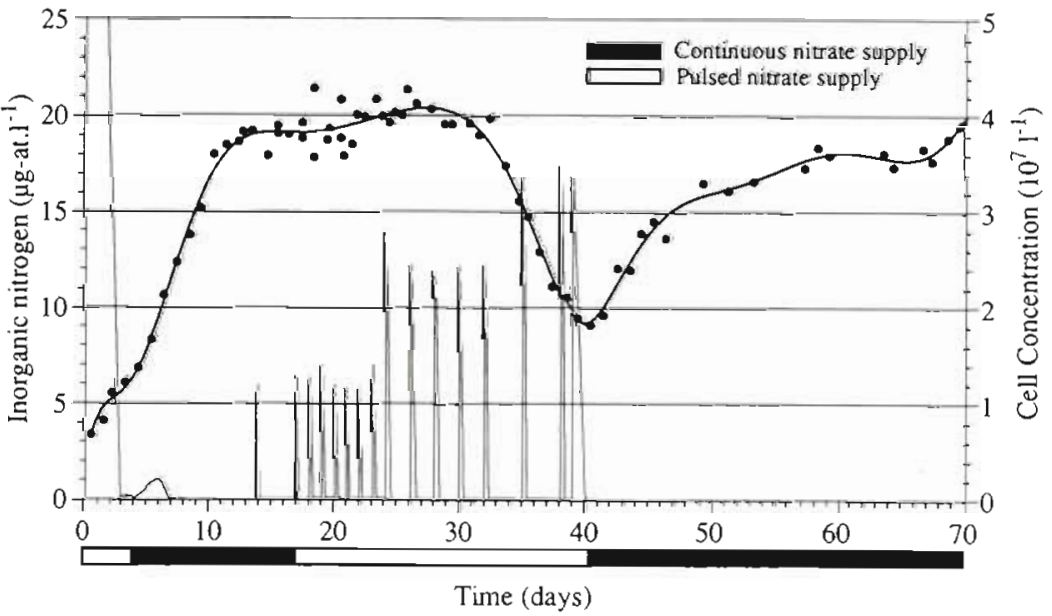


Table 1. Modes of nitrate additions into the chemostat during the $70 \mathrm{~d}$ time-course experiment

\begin{tabular}{|c|c|c|c|c|}
\hline Day & $\begin{array}{c}\text { Inflow } \\
\text { medium with } \\
\mathrm{NO}_{3}\end{array}$ & $\begin{array}{l}\text { No, of } \\
\text { pulses }\end{array}$ & $\begin{array}{c}\text { Pulse of } \mathrm{NO}_{3} \\
\text { Amount } \\
\text { ( } \mu \mathrm{g} \text {-at. } \mathrm{Nl}^{-1} \text { ) }\end{array}$ & $\begin{array}{l}\text { Frequency } \\
\text { (d) }\end{array}$ \\
\hline $0-4$ & - & 0 & - & - \\
\hline $4-17$ & + & 0 & - & - \\
\hline 14 & + & 1 & 6.4 & 1.0 \\
\hline $17-24$ & - & 7 & 6.4 & 1.0 \\
\hline $24-32$ & - & 5 & 12.5 & 2.0 \\
\hline $32-38$ & - & 2 & 19 & 3.0 \\
\hline 39 & - & 1 & 19 & 1.0 \\
\hline $40-70$ & + & 0 & - & - \\
\hline
\end{tabular}

the stabilized growth rate obtained in continuous supply (Fig. 2). During the first $12 \mathrm{~d}$ of pulsed supply, cell concentration increased slightly, probably because the steady state was not completely achieved at Day 17 During the period of low frequency of nitrate input (Days 32 to 38 ), the growth rate decreased drastically to very low values $\left(0.03 \mathrm{~d}^{-1}\right)$. Just after the last pulse of nitrate (Day 39) which occurred only $1 \mathrm{~d}$ after the previous one, growth rate increased and reached a maximum only $2 \mathrm{~d}$ after the previous minimum. Once the continuous supply of nitrogen was resumed at Day 40 , the cell concentration immediately tended towards the level previously obtained at the steady state, but more slowly. The longer time taken by the cell population to recover its initial steady-state level may be due

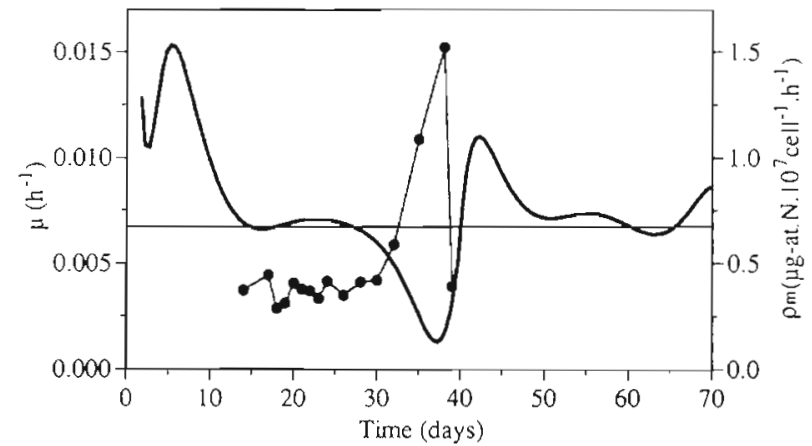

Fig. 2. Prorocentrum minimum. Continuous line: growth rate during the $70 \mathrm{~d}$ time-course experiment. Line with data points: maximum uptake rates measured during each pulsed experiment. Horizontal line represents dilution rate

to the physiological integration of previous growth conditions during the pulsed phase.

During the pulsed phases, the mean amount of nitrogen injected each day by the peristaltic pump (ca 6.60 $\mu$ g-at. $\mathrm{N}^{-1} \mathrm{~d}^{-1}$ ) was similar to that of the continuous period (ca $6.72 \mu \mathrm{g}$-at. $\mathrm{N}^{-1} \mathrm{~d}^{-1}$ ). Given that the dilution rate was low, and that the amounts of nitrate added were rapidly exhausted over 0.2 to $0.5 \mathrm{~d}$ (except for the last one, see below), the amount of nitrogen loss by dilution between Days 17 and 40 constituted only $6.05 \mu \mathrm{g}$-at. $\mathrm{N} \mathrm{l}^{-1}$, which is $4 \%$ of the total amount of nitrogen injected. This means that, in comparison with the continuous supply, $96 \%$ of the supplied nitrogen was taken up by the culture during the pulsed regime. Further, the amount of nitrate taken up per cell after
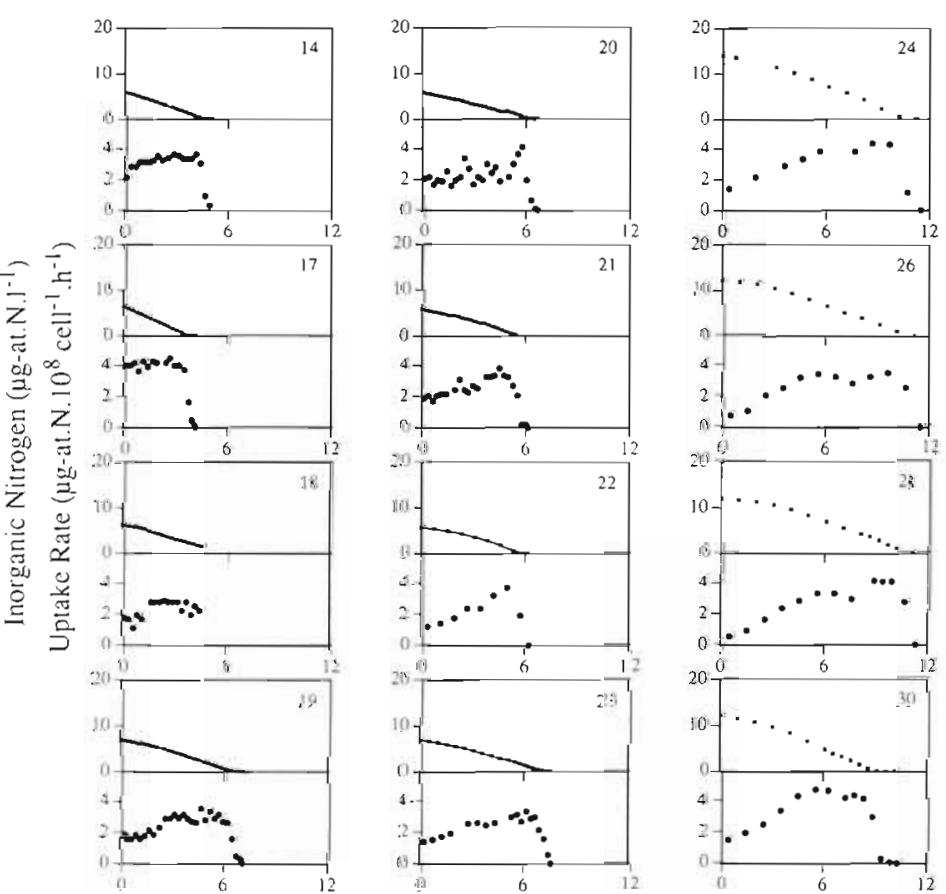

Time (h)

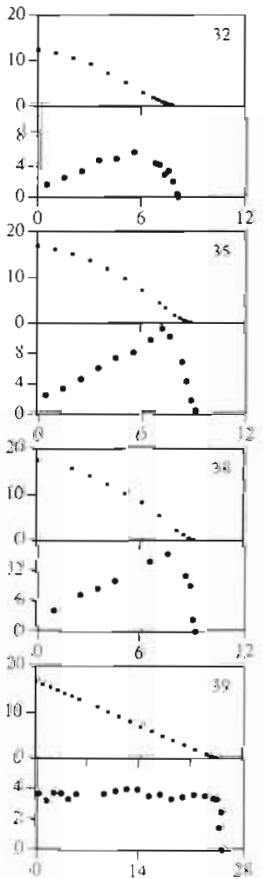

Fig. 3. Time variation of inorganic nitrogen ( $\mathbf{m}$ ) and uptake rate of Prorocentrum minimum $(\bullet)$ following nitrate additions. Numbers in right-hand corner indicate the day of the pulsed experiments. Note difference in uptake scales for Days 32 , 35 and 38 
Day 32 was higher than previously since the same amount of nitrogen was added to a decreasing cell population. The $4 \%$ difference is probably not sufficient to explain by itself the fall observed in growth rate. In this experiment, the sensitivity of Prorocentrum minimum to limiting nitrogen supplies depended essentially on the frequency of nutrient pulses. Given the amount of nitrogen supplied, periodicities of 1 and $2 \mathrm{~d}$ did not affect growth of $P$. minimum, whereas a periodicity of $3 \mathrm{~d}$ was limiting.

Fig. 3 depicts the time-course variation of nitrogen concentration and uptake rate for each pulse experiment. (Time series 18 was interrupted due to autoanalyser pump damage.) The most noticeable effect which can be observed overall is the increase of the non-linearity of uptake rate during the pulsed period. The rate measured on cells at steady state (Day 17) reached a maximum $\left(\rho=4.0 \times 10^{-8} \mu \mathrm{g}\right.$-at. $\left.\mathrm{N} \mathrm{cell}^{-1} \mathrm{~h}^{-1}\right)$ a short time after the onset of the pulse. The initial uptake rates of the ensuing perturbation experiments were lower and decreased with time. A few hours were necessary to reach a more or less constant uptake rate before entering the external control phase corresponding to substrate depletion. This pattern is characteristic of nitrogen-limited cells (Eppley et al. 1969, Caperon \& Meyer 1972, Collos 1980, Romeo \& Fisher 1982). The values of the maximum uptake rate attained at each pulse experiment are shown in Fig. 2. In contrast with the time elapsed before Day 32, during which there was no significant variation of the maximum uptake rate, a marked increase is visible afterward, which is concomitant with the growth rate decrease. The first uptake rate significantly exceeding $5.0 \times 10^{-8} \mu$ g-at. $\mathrm{N}$ cell ${ }^{-1} \mathrm{~h}^{-1}$ was measured during the last $2 \mathrm{~d}$ pulse experiment, and suggests that enhanced uptake became induced during the $2 \mathrm{~d}$ pulsed phase

The maximum uptake rate was immediately attained for the last perturbation experiment (Day 39) which was carried out only $1 \mathrm{~d}$ after the previous pulse (instead of $3 \mathrm{~d}$ ), and the estimated uptake rate was quite similar to that measured during the first perturbation experiment. Moreover, the growth rate increased rapidly 1 d later.

Fig. 4 shows the nitrogen uptake kinetics obtained for perturbation experiments in which a maximum steady uptake rate was sustained by cells for a certain time before its decrease due to nitrogen depletion. In comparison with the values commonly obtained for dinoflagellates or even for diatoms (Eppley et al. 1969), our half-saturation constants are unexpectedly low. This can probably explained by the fact that total inorganic nitrogen was measured without distinction between nitrate and nitrite. Fig. 5 shows the appearance of nitrite and its subsequent uptake after an addition of $8 \mu \mathrm{g}$-at. $\mathrm{N}-\mathrm{NO}_{3} \mathrm{I}^{-1}$ to a $\mathrm{N}$-limited culture of

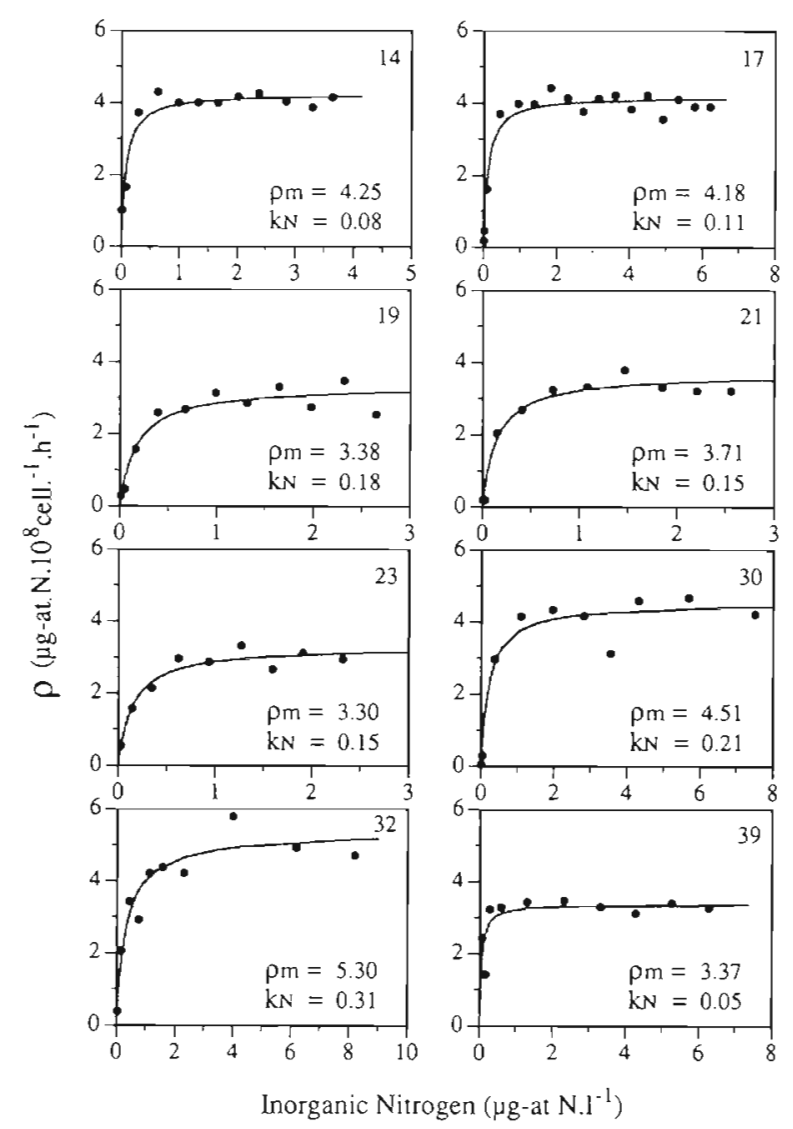

Fig. 4. Prorocentrum minimum. Nitrogen uptake kinetics obtained from perturbation experiments during which cells sustained a stable uptake rate before limitation due to nutrient deprivation. Numbers in right-hand corner indicate day of pulsed experiments

Prorocentrum minimum grown in an identical culture system at the same dilution rate. More than $5 \%$ of the nitrate added was excreted at an average rate of $1.7 \times 10^{-9} \mu \mathrm{g}$-at. $\mathrm{N}$ cell ${ }^{-1} \mathrm{~h}^{-1}$. For concentrations of nitrate below $2 \mu \mathrm{g}$-at. $\mathrm{Nl}^{-1}$, the proportion of nitrite became important, and nitrite uptake increased

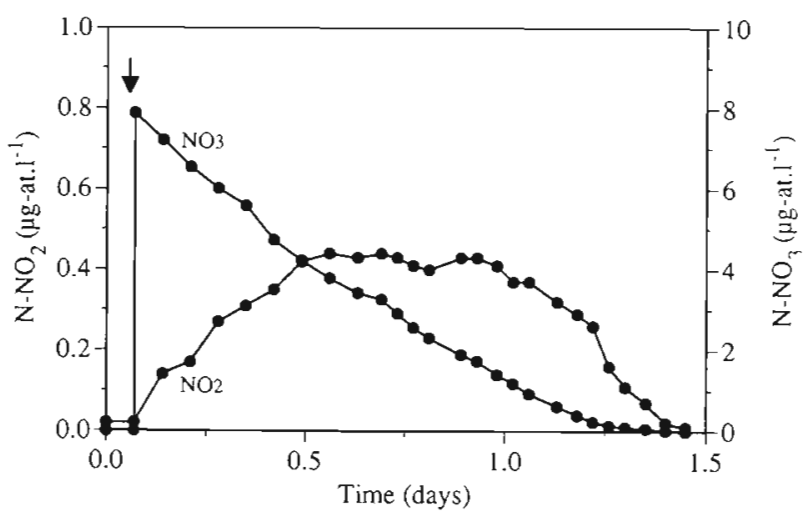

Fig. 5. Changes in nitrate and nitrite in a chemostat culture of nitrate-limited cells of Prorocentrum minimum following a nitrate addition 


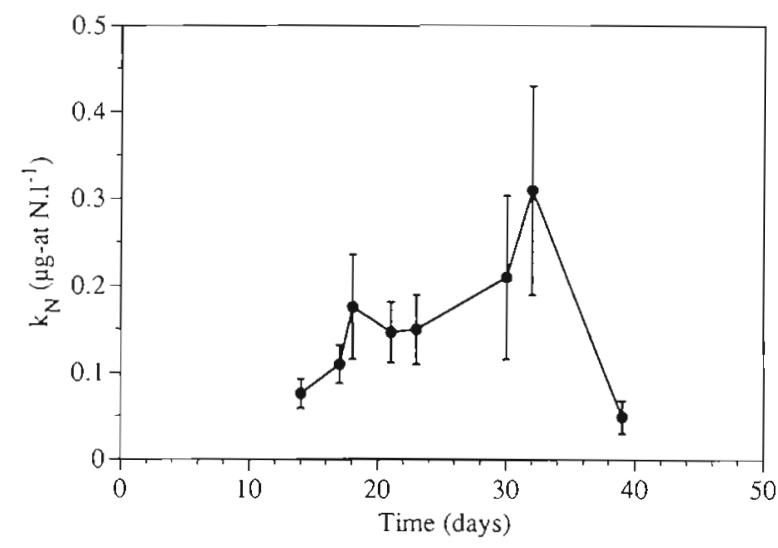

Fig. 6. Time variation in $k_{\mathrm{N}}$ estimated from the nitrate uptake kinetics presented in Fig. 4. Confidence intervals are represented by 2 standard-deviation bars

rapidly. It follows that, if nitrate is not measured separately from nitrite, the uptake rate of nitrate may be underestimated when cells excrete nitrite, and overestimated when cells take up nitrite toward the end of incubation. This artifact leads to an underestimate of $k_{\mathrm{N}}$ (Collos 1982). Estimated values of the $k_{N}$ constant are shown in Fig. 6 and one sees the variation of 'global affinity' of cells for total inorganic nitrogen. A noticeable increase occurred at Day 32 which corresponds to the increase of $\rho_{m}$. Nevertheless, it is impossible now to distinguish whether this effect resulted from a true variation of the nitrate affinity, or from a decrease of nitrite excretion with time. In any case, the variation of the estimated half-saturation constant could reflect important changes in nitrogen metabolism.

\section{DISCUSSION}

The discrepancy found in the literature on the effects of sudden nutrient pulses on growth or uptake rates (Collos 1986) may originate from the diverse physiological conditions in which cells are placed before the measurements of growth and uptake (Elrifi \& Turpin 1987, Raimbault \& Mingazzini 1987). A single stimulus is, in most cases, performed on cells where the degree of deprivation of the limiting nutrient is not very well defined (Collos 1983, Dortch et al. 1984). The distinction between 'limited' and 'starved' cells is somewhat arbitrary in that the cell quota is not at its theoretical maximum in the first case, and near its minimum value in the second case. But the nitrogen cell quota is a global index which represents the total amount of cellular nitrogen, without defining composition. In fact, under limitation, deprivation or resupply conditions, the structural, synthetic and genetic components which compose the nitrogen pool are differently affected (Dortch 1982), following hierarchical and complex processes (Wheeler 1983, Raimbault \& Mingazzini 1987. Falkowski et al. 1989).

In this study, physiological adaptation appeared at different time scales following the frequency of nitrate pulses. For all of the perturbation experiments, except the first and the last, a non-linearity of the uptake rate was observed which reflects a mid-term adaptation of cells when they are pulsed with nitrate. The sampling step was not small enough to detect the existence of a surge uptake rate (Conway et al. 1976) in the early phase of the perturbation experiments, which might have resulted from a well-known but not systematic short-term adaptation. During the $1 \mathrm{~d}$ pulsed phase, and a part of the $2 d$ pulsed phase, a maximal and steady uptake rate, approximately the same as that found at steady state, was maintained for a time. Thus, it can be supposed that cells had completed their mid-term adaptation. No significant variation of either the maximum uptake rate or the growth rate was apparent during this period.

By contrast, a long-term adaptation appeared as the culture received nitrate once every 2 or $3 \mathrm{~d}$. This longterm adaptation was characterized by the increase of the maximum uptake rate over the time-course experiment. During the $2 \mathrm{~d}$ pulsed phase, the maximum uptake rate measured began to increase only after the fifth addition of nitrate, suggesting that the effects of this regime were delayed. Afterwards, the maximum uptake rate exceeded its steady state value 3 - or 4 -fold. It can be seen from Fig. 2 that the growth rate began to be significantly affected as the long-term adaptation became more evident.

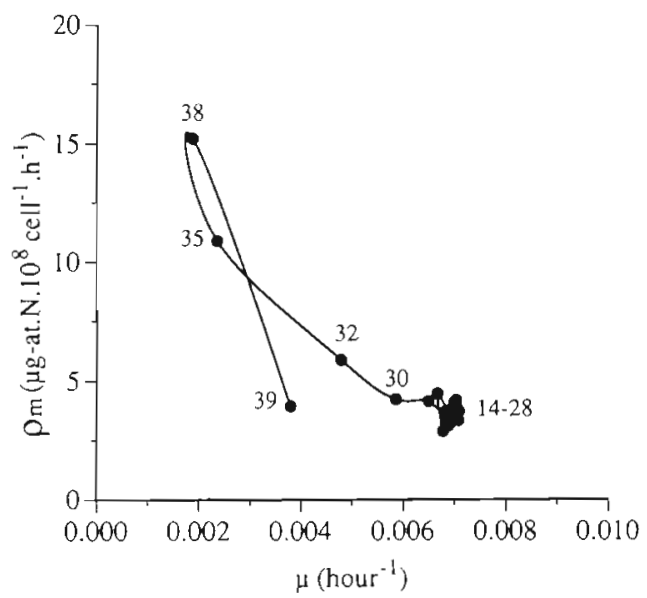

Fig. 7 Prorocentrum minimum. Time changes in growth and uptake rates during the pulsed phase. The 2 processes become largely uncoupled for the 3 d pulsed phase. Numbers indicate pulsed experment ctays 
For Prorocentrum minimum, uptake and growth are largely uncoupled (Fig. 7). What is interesting is the fact that, although the culture absorbed approximately the same amount of nitrate during all the time-course experiments, its conversion into growth is greatly dependent on the frequency of availability The frequency of 1 pulse per day induced a non-linearity in the uptake process which reflected a mid-term adaptation sufficient to ensure a constant growth rate. For lower frequencies and higher amplitudes of nitrate additions, the non-linearity of uptake rate was increased, which reflected a strong adaptation, whose efficiency was however not sufficient to maintain the same growth rate. In both situations, approximately the same amount of nutrient was absorbed. Since growth rate decreased with low frequency additions, it may be supposed that a part of the absorbed nitrogen was excreted as dissolved organic nitrogen, not measured here. It may be argued that during the phase where nitrate was added once a day, only the most labile forms of nitrogen as nitrate and amino acids in the cell were used, whereas in the other patterns of discrete distribution, more structural or functional components such as proteins were degraded to satisfy the nitrogen requirement of cells (Dortch 1982). To compensate their loss of material, cells increase their uptake rate when nitrate is again available in a manner which depends on the severity of the deprivation. As the enhancement of the associated assimilation processes requires the synthesis of energetic and enzymatic materials, an induction time is observed before the uptake rate reaches its maximum.

Logically, it can be expected that once the cells have recovered their nitrogen needs, the uptake will reach a constant rate. This was effectively the case for the $1 \mathrm{~d}$ and a part of the $2 \mathrm{~d}$ pulsed phases. Afterwards (Days $32,35,38$ ), the uptake rate increased without reaching stability. In this case, the non-linearity probably reflects an unbalanced growth. The nitrogen requirement of the cells was not met, and growth rate immediately decreased.

Despite this, it is interesting to note from Fig. 3 that, if a large amount of nitrate is added only $1 \mathrm{~d}$ after the previous pulse (see Day 39), the cells recover their ability to take up nitrogen in the same manner as in the steady state (see Day 17), and thus their nitrogen demands have been completely satisfied. The contrast observed in the time variations of the uptake rate between Days 38 and 39 (Fig. 7) reflects a considerable intracellular rearrangement. The effects of the enhanced uptake of nitrogen at Day 38 on the energetic balance of starved cells were delayed with a time lag shorter than $1 \mathrm{~d}$. It has to be noted that, in this case, such rapid changes in uptake data cannot lead to extrapolations of growth.
Cell division began to increase $1 \mathrm{~d}$ after the end of the last pulse experiment (Day 39) concurrent to the resumption of the continuous nitrate inflow Such a time lag between nitrogen resupply and growth and the observation that regimes of 1 and 2 d pulsed nitrate have no effect on the growth rate of Prorocentrum minimum suggests that this species has the capability of accumulating large internal nutrient pools. This type of response is ecologically advantageous when nutrient pulsing frequency is lower than cell division rate (Collos 1986).

Besides the multiple forms of adaptation that Prorocentrum minimum can develop in response to different spectral qualities and irradiances (Vogel \& Sager 1985 , Coats \& Harding 1988, Harding 1988, Harding \& Coats 1988, and others), Paasche et al. (1984) have demonstrated the ability of this species to maintain high nitrogen uptake rates during the dark phase of a 12:12 $h$ L:D cycle. This feature could permit the separation in time of photosynthesis (near the surface, in daytime) and nitrogen uptake (at depth, during the night) and would confer on this species or other dinoflagellates a competitive advantage over diatoms (Eppley \& Harrison 1975, Harrison 1976). Tyler \& Seliger (1981) reported that in the Chesapeake Bay, USA, during late summer where nutrient concentration in the highly stratified bay may decrease in surface waters, blooms of $P$. minimum often persist and exhibit significant carbon uptake. Previous observations in the same area have demonstrated the ability of this species to migrate at night to the higher nutrient pycnocline region. This ecological phenomenon may represent a real advantage only if the species is able to support several hours per day of nitrogen deprivation. Our conclusion that $P$. minimum maintains an unchanged growth rate under a $1 \mathrm{~d}$ pulsed nitrate regime reinforces the hypothesis that this species may have a behavioral pattern of vertical migration that may significantly reduce the effects of nutrient depletion.

Acknowledgements. I thank Gilbert Malara for his technical assistance concerning the elaboration of the automatic chemostat culture system, Patrick. Chang for improving the English, and the anonymous reviewers for their comments and suggestions. This research was supported by funds from the Ministère de l'Environnement (National Program: Efflorescences Algales Marines) and by CNRS (Département TOAE; UA7 16: Ecologie du Plancton marin).

\section{LITERATURE CITED}

Burmaster, D. E. (1979). The continuous culture of phytoplankton: mathematical equivalence among three steadystate models. Am. Nat. 113: 123-134

Caperon, J., Meyer, J. (1972). Nitrogen-limited growth of marine phytoplankton. I. Changes in population characteristics with steady-state growth rate. Deep Sea Res. 19: $601-618$ 
Coats, D. W., Harding, L. W. (1988). Effect of light history on the ultrastructure and physiology of Prorocentrum mariaelebouriae (Dynophyceae). J. Phycol. 24: 67-77

Collos, Y. (1980). Transient situations in nitrate assimilation by marine diatoms. I. Changes in uptake parameters during nitrogen starvation. Limnol. Oceanogr. 25: 1075-1081

Collos, Y (1982). Transient situations in nitrate assimilation by marine diatoms. II. Changes in nitrate and nitrite following a nitrate perturbation. Limnol. Oceanogr. 27: 528-535

Collos, Y (1983). Transient situations in nitrate assimilation by marine diatoms. IV Non-linear phenomena and the estimation of the maximum uptake rate. J. Plankton Res. 5: $677-691$

Collos, Y (1986). Time-lag algal growth dynamics: biological constraints on primary production in aquatic environments. Mar Ecol. Prog. Ser 33: 193-206

Conway, H. L., Harrison, P. J., Davis, O. (1976). Marine diatoms grown in chemostats under silicate or ammonium limitation. II. Transient response of Skeletonema costatum to a single addition of the limiting nutrient. Mar. Biol. 35: $187-199$

Cunningham, A. (1984). The impulse response of Chlamydomonas reinhardii in nitrite-limited chemostat culture Biotechnol. Bioengng. 26: 1430-1435

Cunningham, A.. Maas, P. (1978). Time lag and nutrient storage effects in the transient growth response of Chlamydomonas reinhardii in nitrogen-limited batch and continuous culture. J. gen. Microbiol. 104: 227-231

DeManche, J. M., Curl, H. C., Lundy, D. W., Donaghay, P. L. (1979). The rapid response of the marine diatom Skeletonema costatum to changes in external and internal nutrient concentration. Mar. Biol. 53: 323-333

Denman, K. L., Gargett, A. E. (1983). Time and space scales of vertical mixing and advection of phytoplankton in the upper ocean. Limnol. Oceanogr 28: 801-815

Dortch, Q. (1982). Effect of growth conditions on accumulation of internal nitrate, ammonium, amino acids, and protein in three marine diatoms. J. exp. mar Biol. Ecol. 61 243-264

Dortch, Q., Clayton, J. R., Thoresen, S. S., Ahmed, S. I. (1984) Species differences in accumulation of nitrogen pools in phytoplankton. Mar. Biol. 81. 237-250

Droop, M. R. (1968). Vitamin B12 and marine ecology. IV The kinetics of uptake growth and inhibition in Monochrysis lutheri. J. mar. biol. Ass. U.K. 48: 689-733

Elrifi, I. R., Turpin, D. H. (1987). Short-term physiological indicators of $\mathrm{N}$ deficiency in phytoplankton: a unifying model. Mar Biol. 96: 425-432

Eppley, R. W., Harrison, W. G. (1975). Physiological ecology of Gonyaulax polyedra, a red water dinoflagellate of southern California. In: LoCicero, V. R. (ed.) Toxic dinoflagellate blooms. Proc. Intl. Conf. (1st) Mass. Sci. Technol. Fndn., Wakefield, p. 12-22

Eppley, R. W., Rogers, J. N., McCarthy, J. J. (1969). Halfsaturation constants for uptake of nitrate and ammonium by marine phytoplankton. Limnol. Oceanogr 14 912-920

Falkowski, P. G., Sukenik, A., Herzig, R. (1989). Nitrogen limitation in Isochrysis galbana (Haptophyceae). II. Relative abundance of chloroplast proteins. J. Phycol. 25: $471-478$

Goldman, J. C., Taylor, C. D., Glibert, P. (1981). Nonlinear time-course uptake of carbon and ammonium by marine phytoplankton. Mar Ecol. Prog. Ser. 6: 137-148

Goldman, J. C., McCarthy, J. J. (1978). Steady state growth and ammonium uptake of a fast-growing marine diatom. Limnol. Oceanogr. 23: 695-703

Guillard, R. R., Ryther, J. H. (1962). Studies on marine plank- tonic diatoms. I. Cyclotella nana Hudtedt and Detonula confervaceae (Cleve) Gran. J. Microbiol 8: 229-239

Harding, $W \mathrm{H}$. (1988). The time course of photoadaptation to low-light in Prorocentrum mariae-lebouriae (Dinophyceae). J. Phycol. 24: 274-281

Harding, L. W., Coats, D. W. (1988). Photosynthetic physiology of Prorocentrum mariae-lebouriae (Dinophyceae) during its subpycnocline transport in Chesapeake bay. J. Phycol. $24: 77-89$

Harris, G. P. (1984). Phytoplankton productivity and growth measurements: past, present and future. J. Plankton Res. 6: $219-237$

Harris, G. P. (1986). Phytoplankton ecology: structure, function and fluctuation. Chapman and Hall Ltd, London

Harrison, W. G. (1976). Nitrate metabolism of the red tide dinoflagellate Gonyaulax polyedra Stein. J. exp. mar. Biol. Ecol. 21: 199-209

Harrison, P. J., Parslow, J. S., Conway, H. L. (1989). Determination of nutrient uptake kinetic parameters: a comparison of methods. Mar Ecol. Prog. Ser. 52: 301-312

Klein, P., Coste, B. (1984\}. Effects of wind-stress variability on nutrient transport into the mixed layer. Deep Sea Res. 31 . 21-37

Marra, J., Bidigare, R. R., Dickey, T D. (1990). Nutrients and mixing, chlorophyll and phytoplankton growth. Deep Sea Res. 1: $127-143$

McCarthy, J. J. (1981). The kinetics of nutrient utilization. In: Platt, T (ed.) Can. Bull. Fish. Aquat. Sci. 210: 211-233

McCarthy, J. J., Altabet, M. A. (1984). Patchiness in nutrient supply: implication for phytoplankton ecology. In: Meyers, D. G., Strickler, J. R. (eds.) Trophic interactions within aquatic ecosystems. Vol. 85, AAAS Selected Symposium, p. $29-45$

Monod, J. (1942). Recherches sur la croissance des cultures bactériennes, 2nd edn. Herman et Cnie, Paris

Murphy, T P. (1980). Ammonia and nitrate uptake in the lower Great Lakes. Can. J. Fish. Aquat. Sci. 37: 1365-1372

Olsen, Y., Vadstein, O., Andersen, T., Jensen, A. (1989). Competition between Staurastrum luetkemuellerii (Chlorophyceae) and Microcystis aeruginosa (Cyanophyceae) under varying modes of phosphate supply. J. Phycol. 25: 499-508

Paasche, E., Bryceson, I., Tangen, K. (1984). Interspecific variation in dark nitrogen uptake by dinoflagellates. J. Phycol. 20: $394-401$

Quarmby, L. M., Turpin, D. H., Harrison, P. J. (1982). Physiological responses of two marine diatoms to pulsed additions of ammonium. J. exp. mar. Biol. Ecol. 63: 173-181

Raimbault, P., Mingazzini, M. (1987). Diurnal variations of intracellular nitrate storage by marine diatoms: effects of nutritional state. J. exp. mar Biol. Ecol. 112: 217-232

Romeo, A. J., Fisher, N. S. (1982). Intraspecific comparisons of nitrate uptake in three marine diatoms. J. Phycol. 18: 220-225

Sommer, U. (1985). Comparison between steady state and non-steady state competition: experiments with natural phytoplankton. Limnol. Oceanogr. 30: 335-346

Suttle, C. A., Stockner, J. G., Harrison, P. J. (1987). Effects of nutrient pulses on community structure and cell size of a freshwater phytoplankton assemblage in culture. Can. J. Fish. Aquat Sci. 44: 1768-1774

Tréguer, P., Le Corre, P. (1975). Manuel d'analyse des sels nutritifs dans l'eau de mer Laboratoire d'Océanologie et de Chimie. Université de Bretagne Occidentale, Brest

Turpin, D. H., Parslow, J. S., Harrison, P. J. (1981). On limiting nutrient patchiness and phytoplankton growth: a conceptual approach. J. Plankton Res 3: 421-431

Tyler, M. A., Seliger, H. H. (1978). Annual subsurface trans- 
port of a red tide dinoflagellate to its bloom area: water circulation patterns and organism distributions in the Chesapeake Bay. Limnol. Oceanogr 23: 227-237

Tyler, M. A., Seliger, H. H. (1981). Selection for a red tide organism: physiological responses to the physical environment. Limnol. Oceanogr 26: 310-324

Vogel, H., Sager, J. C. (1985). Photosynthetic response of Prorocentrum mariae-lebouriae (Dinophyceae) to differ-

This article was submitted to the editor ent spectral qualities, irradiances, and temperatures. Hydrobiologia 128: 143-153

Wheeler, P. A. (1983). Phytoplankton nitrogen metabolism. In: Carpenter, E. J., Capone, D. G. (eds.) Nitrogen in the marine environment, Vol. 9. Academic Press Inc., New York, p. 309-346

Woods, J. D., Wiley. R. L. (1972). Billow turbulence and ocean microstructure. Deep Sea Res. 19: 87-121

Manuscript first received: November 12, 1990

Revised version accepted: March 18, 1991 